\title{
Development and early life history behaviour of aquarium reared Syngnathus acus (Pisces: Syngnathidae)
}

\author{
K. Silva* ${ }^{\dagger \S}$, N.M. Monteiro ${ }^{\dagger \ddagger}$, V.C. Almada ${ }^{\int}$ and M.N. Vieira* ${ }^{\dagger}$ \\ * Departamento de Zoologia e Antropologia da Faculdade de Ciências da Universidade do Porto, Praça Gomes Teixeira, \\ 4099-002 Porto, Portugal. ${ }^{\dagger}$ CIIMAR, Rua dos Bragas 177, 4050-123 Porto, Portugal. ${ }^{\ddagger}$ Faculdade de Ciências da Saúde da Universidade \\ Fernando Pessoa, Rua Carlos da Maia 296, 4200-150 Porto, Portugal. ISPA, Rua Jardim do Tabaco 34, 1149-041 Lisboa, Portugal. \\ ${ }^{\S}$ Corresponding author, e-mail: ksilva@fc.up.pt
}

\begin{abstract}
Some notes on development and early life history behaviour of aquarium-reared Syngnathus acus are presented and compared with other syngnathid species, namely S. abaster. Implications in population dynamics and connectivity are discussed.
\end{abstract}

The family Syngnathidae is remarkable for its adaptations for parental care, with females depositing eggs in a male's specialized incubating area where embryos are protected, nourished and osmoregulated (Vincent et al., 1992). Despite the ubiquitous male brooding of the egss, the anatomical organization of the brooding structures varies in complexity, from a simple ventral surface where eggs are brooded openly without any protective plates or covering membranes, to a brood pouch (marsupium) with different degrees of closure culminating in the sealed sacklike pouch of seahorses (Herald, 1959). This gradient in conspicuous male paternal care structures was used to construct a phylogeny (Herald, 1959) that was later largely confirmed by Wilson et al. (2003) using mitochondrial DNA.

A comparative study of three different brood structures (Nerophis ophidion, Syngnathus abaster and Hippocampus hippocampus; pouch types B1, A4i and A5, respectively, (Herald, 1959)) showed that each structure had a skin with a different ultrastructure, suggesting different functions that may be related to different reproductive strategies of each species (Carcupino et al., 2002). Recent work suggested that the anatomical variations among brooding structures could also signal distinct early life histories with different degrees of newborn development being associated with contrasting dispersal potentials (Silva et al., 2006). As a fact, within pipefish, marsupium lacking species, such as Nerophis lumbriciformis, seem to produce smaller and less developed planktonic larvae, with a morphology still distant from the adult (Monteiro et al., 2003), while species with a marsupium, such as $S$. abaster, give birth to fully formed juveniles that immediately assume a benthic distribution on release from the parent's pouch (Silva et al., 2006). The ultrastructural changes related to the increased elaboration of pipefish brooding structures seem, thus, to be accompanied by an increase in the extent of newborn development along with a transition from a two-phase life history (planktonic larvae and benthic adults) to an apparently single benthic strategy (Silva et al., 2006).

Larvae biology and behaviour of most syngnathid species remain, however, undocumented and variation in early life history parameters across genera requires thorough analysis in order to correctly assess the mechanisms and strategies involved in syngnathid evolution. Furthermore, increasing knowledge on early life history related parameters could provide powerful insights into the relative vulnerability of different species or populations to the actual increasing pressures presented through overexploitation and habitat fragmentation.

In this paper, some notes on the development of aquarium-reared juveniles of the greater pipefish, Syngnathus acus Linnaeus, a data deficient species (Baillie et al., 2004), are presented. Simultaneously, the vertical distribution of newborns was analysed as an indication of the benthic or pelagic nature of the juveniles, a variable with profound implications in the population dynamics of pipefish that inhabit increasingly fragmented habitats, such as eelgrass meadows. Comparisons are also presented, highlighting similarities and differences between $S$. acus and other western European pipefish species, particularly $S$. abaster.

Syngnathus acus juveniles were obtained from four pregnant males captured by net in the Ria de Aveiro estuarine lagoon $\left(40^{\circ} 45^{\prime} \mathrm{N} 8^{\circ} 40^{\prime} \mathrm{W}\right)$, in Portugal. Captive males were fed daily with fresh Artemia franciscana nauplii and maintained in 250-1 aquaria, illuminated with natural light, supplemented with $18 \mathrm{~W}$ fluorescent lamps. Due to the 'gas bubble disease' aeration was performed outside the fish tanks. Continuously running seawater was physically and biologically filtered and temperature maintained at $18-19^{\circ} \mathrm{C}$. Due to the direct observation of cannibalism, newborns were separated from males and maintained in 80-1 aquaria, in the same conditions as adults.

Total length (TL) of ten juveniles haphazardly collected from the tank was measured every week up to two months after birth.

The vertical distribution of juveniles was analysed as in Silva et al. (2006) by separately placing individuals inside small 4 -l aquaria $(40 \times 10 \times 10 \mathrm{~cm})$ with no water circulation, divided in three sections: surface $(10 \mathrm{~cm})$, middle section $(20 \mathrm{~cm})$ and bottom $(10 \mathrm{~cm})$. After an initial accommodation period ( $\approx 45 \mathrm{~min}), 10 \mathrm{~min}$ observation periods were conducted on the time juveniles spent in the 
A

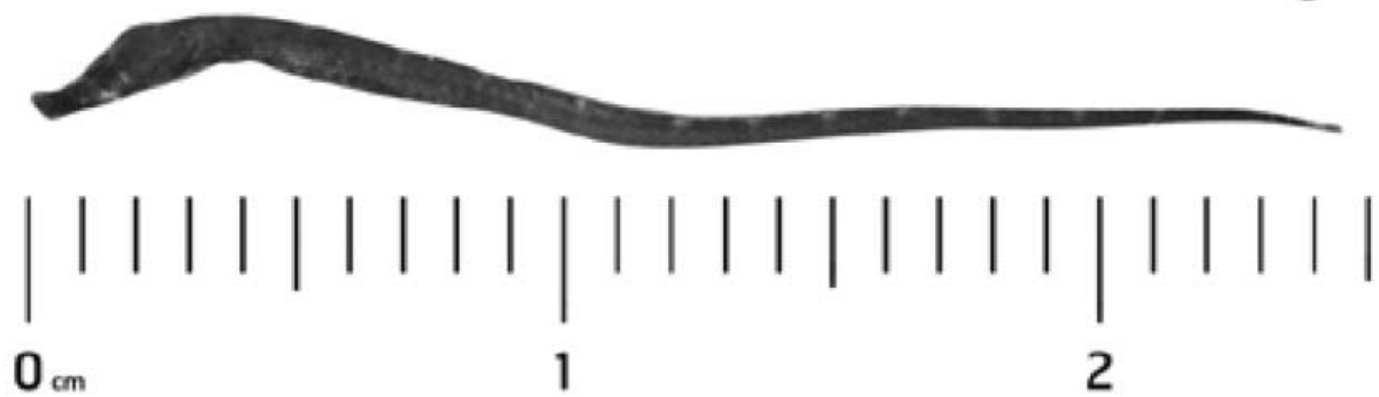

B

\begin{tabular}{|c|c|c|c|c|c|c|c|}
\hline Species & Body rings & Snout & Eye & Dorsal fin & Anal fin & Caudal fin & Pectoral fin \\
\hline Syngnathus acus ${ }^{1}$ & $\begin{array}{l}54-57 \text { (trunk } \\
\text { rings: } 18-19 \text {; tail } \\
\text { rings: } 36-38 \\
\text { rings under the } \\
\text { dorsal fin: } 8 \text { ) }\end{array}$ & $\begin{array}{l}\text { equal or less } \\
\text { than half of head }\end{array}$ & $\begin{array}{l}\text { more than twice } \\
\text { the preorbital } \\
\text { space }\end{array}$ & $\begin{array}{l}\text { longer than the } \\
\text { head; } 33-35 \text { rays }\end{array}$ & 3-4 rays & $8-10$ rays & 13 rays \\
\hline Syngnathus abaster ${ }^{2}$ & $\begin{array}{l}46-48 \text { (trunk } \\
\text { rings: } 14-15 ; \text { tail } \\
\text { rings: } 32-33 ; \\
\text { rings under the } \\
\text { dorsal fin: } 7 \text { ) }\end{array}$ & $\begin{array}{l}\text { more than half of } \\
\text { head length }\end{array}$ & $\begin{array}{l}\text { comprised } 1.5 \\
\text { times in the } \\
\text { preorbital space }\end{array}$ & $\begin{array}{l}\text { shorter than the } \\
\text { head; } 26-28 \text { rays }\end{array}$ & 3 rays & $8-9$ rays & 12 rays \\
\hline
\end{tabular}

Diagnostic character: ${ }^{1}$, Median post-orbital portion of head elevated, especially in the adults. ${ }^{2}$, Median post-orbital portion of head not elevated.

\section{C}

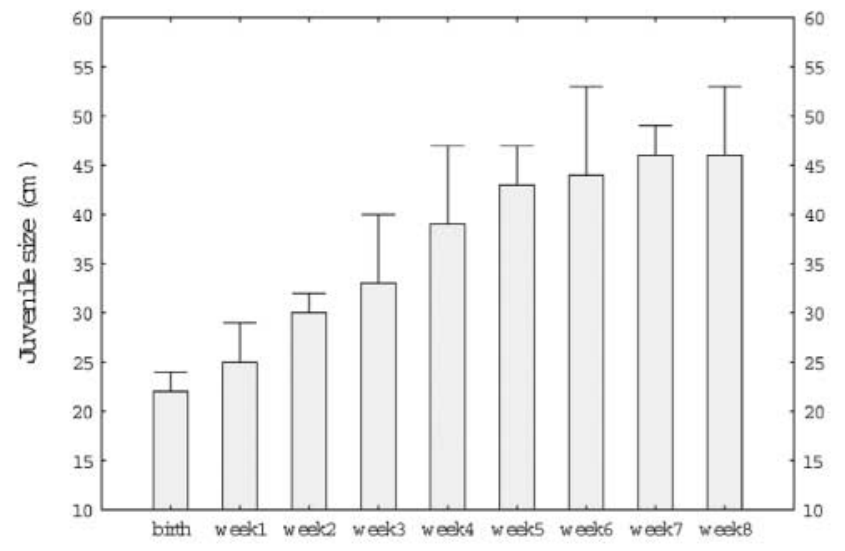

D

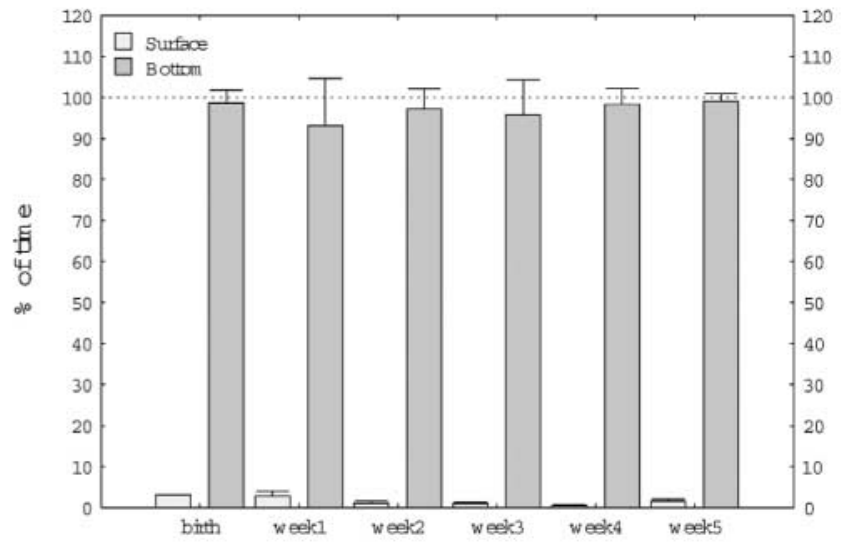

Figure 1. (A) Syngnathus acus newborns; (B) comparison of meristic characters of Syngnathus acus and Syngnathus abaster newborns; (C) juvenile growth rate during the first eight weeks. Error bars represent standard deviations; and (D) vertical distribution in the water column displayed by juveniles during the first five weeks after abandoning the marsupium. Error bars represent standard deviations.

'surface' and 'bottom' sections. In order to assure data independence, each observation was conducted using different individuals, that were only used once (ten trials measuring time spent near the surface and another ten trials aimed at measuring time spent in the bottom section). This experimental design was consecutively repeated during five weeks, always using different individuals. Results were analysed and further compared with data for S. abaster (Silva et al., 2006) through a three factor non-parametric analysis of variance [species (2 levels $=S$. acus and $S$. abaster) time (3 levels $=3$ weeks after birth) and vertical position (2 levels=surface and 
Table 1. Non-parametric analysis of variance results on the vertical distribution of Syngnathus acus and Syngnathus abaster during the first three weeks after abandoning the marsupium.

\begin{tabular}{|c|c|c|c|c|}
\hline $\begin{array}{l}\text { Source of } \\
\text { variation }\end{array}$ & $\begin{array}{l}\text { Degrees } \\
\text { of } \\
\text { freedom }\end{array}$ & $\begin{array}{l}\text { Sum of } \\
\text { squares }\end{array}$ & H-statistic & $P$ value \\
\hline Species & 1 & 143.01 & 0.134 & 0.7144 \\
\hline Time & 2 & 421.91 & 0.395 & 0.821 \\
\hline Vertical distribution & 1 & 99498.70 & 92.251 & $7.634 \mathrm{E}-22$ \\
\hline Species $\times$ time & 2 & 153.86 & 0.144 & 0.930 \\
\hline $\begin{array}{l}\text { Species } \times \text { vertical } \\
\text { distribution }\end{array}$ & 1 & 12.68 & 0.012 & 0.913 \\
\hline $\begin{array}{c}\text { Time } \times \text { vertical } \\
\text { distribution }\end{array}$ & 2 & 517.988 & 0.485 & 0.785 \\
\hline $\begin{array}{l}\text { Species } \times \text { time } \times \\
\quad \text { vertical distribution }\end{array}$ & 2 & 39.16 & 0.037 & 0.982 \\
\hline Error & 108 & 28459.20 & & \\
\hline Total & 120 & 567476.50 & & \\
\hline Corrected total & 119 & 128246.50 & & \\
\hline
\end{tabular}

bottom)]. Comparison between $S$. acus and S. abaster juvenile birth lengths were assessed through a 2-tailed independent-samples $t$-test. All statistical analyses were performed using the Statistical Package for the Social Sciences 13.0 (SPSS Inc.).

Pregnant males gave birth, during a 2-3 day period, to fully formed juveniles (Figure 1A) measuring approximately $26 \mathrm{~mm}$ ( $\mathrm{TL} ; \mathrm{N}=110$, average $=25.94 \mathrm{~mm}$, range: $17-30 \mathrm{~mm}, \mathrm{SD}=2.52)$ already capable of feeding on Artemia nauplii. Meristic data are presented in Figure 1B. Comparative data for $S$. abaster is also presented (Froese \& Pauly, 2005; K. Silva, personal observation). The two congeneric species resemble each other in general morphology, with, however, some significant differences concerning birth length $[S$. acus: $\mathrm{N}=110$, average $=25.94 \mathrm{~mm}, \quad \mathrm{SD}=2.52 ; \quad S$. abaster: $\quad \mathrm{N}=64$ average $=17.67 \mathrm{~mm}, \quad \mathrm{SD}=2.22 ; \quad$ independent-samples 2-tailed $t$-test: $\mathrm{N}=174, P<0.001]$.

Juveniles used for the calculation of the growth rate (aleatory sampling of aquarium reared juveniles) doubled in size within the first five weeks after abandoning the marsupium (initial size $=22.20 \mathrm{~mm}, \mathrm{SD}=2.30$; five weeks size $=44.30 \mathrm{~mm}, \mathrm{SD}=3.47$ ) (Figure $1 \mathrm{C}$ ). The presence of a fully developed pouch was observed after six months (possible indicator of sexual maturity), in $90 \mathrm{~mm}$ individuals [20\% of the maximum length reported by Dawson (1986) for this species].

A significant difference was observed between time spent in the surface and bottom sections of the aquaria (see Figure 1D). Newborn juveniles occupy the bottom of the aquaria immediately after birth, spending most of the time in close contact with the substrata. Some sporadic movements towards the surface were observed, always rapidly followed by a return to the bottom section of the aquaria. The observed vertical distribution did not significantly change during the following weeks (see Figure 1D). Furthermore, no differences were observed in the vertical distribution pattern of $S$. acus and S. abaster (Table 1).

The observed development and behaviour of $S$. acus juveniles reinforces the idea that the brood pouch of the genus Syngnathus allows for the production of fully formed juveniles that immediately take a bottom life on release from the parent. Contrarily to larvae produced by marsupium-lacking pipefish, whose development is confined to the egg space, Syngnathus larvae remain inside a protective environment that can provide more space to grow and less constrained metabolic exchanges (Monteiro et al., 2005). As a result, species with a marsupium, such as $S$. acus and $S$. abaster give birth to rapidly growing adultlike juveniles, while external brooders produce smaller and less developed larvae, presenting a primordial fin and a transparent coloration (e.g. Nerophis lumbriciformis, $\mathcal{N}$. ophidion and Entelurus aequoreus (Russell, 1976; Monteiro et al., 2003)).

Early life history is determinant in a species' ecology since it has profound implications in demography, dispersal and population connectivity (Cowen et al., 2000; Armsworth, 2002). Species with a pelagic early life stage have, at least theoretically, the capacity to colonize new areas and/or promote gene flow between geographically separated populations, by drifting on water currents. On the other hand, a non-dispersive early life stage may favour genetic differentiation and/or extinction of local populations (Armsworth, 2002).

In the particular case of $S$. acus, a common inhabitant of the increasingly degraded southern European estuarine areas, the apparent benthic strategy of the juveniles, along with habitat fragmentation and degradation, can lead to a decrease in connectivity and consequent isolation between geographically distant populations, in much the same way as it has been documented in S. abaster (Silva et al., 2006). Along the coasts of the Portuguese mainland, these two species seem mainly confined to estuaries (Ré, 1999). Habitat fragmentation and/or long distance colonization, as well as restricted dispersal with isolation by distance have already been pointed out as important forces able to determine the actual geographical distribution of certain seahorse species (Lourie et al., 2005).

A final interesting note on $S$. acus deals with filial cannibalism. Syngnathus acus newborns were actively preyed upon by adults, including their own parents. Cannibalism in pipefish has also been reported in S. abaster (Silva et al., 2006), S. scovelli, S. floridae and S. fuscus (Teixeira \& Musick, 1995), and may be a widespread phenomenon in the genus Syngnathus.

We thank everyone who helped during the fieldwork, especially Alberto Silva, Armando Jorge, Mario Ramalho and Pedro Correia. Vitor Almada and Natividade Vieira's participation were partially funded by Programa Plurianual de Apoio às Unidades de Investigação. Nuno Monteiro's participation was funded by Fundação para a Ciência e a Tecnologia (FCT-SFRH/BPD/ 14992/2004). Karine Silva's participation was funded by Fundação para a Ciência e a Tecnologia (FCT-SFRH/BD/13171/ 2003).

\section{REFERENGES}

Armsworth, P.R., 2002. Recruitment limitation, population regulation, and larval connectivity in reef fish metapopulations. Ecology, 83, 1092-1104.

Baillie, J.C.M., Hilton-Taylor, C. \& Stuart, S.N., ed., 2004. 2004 IUCN Red List of threatened species, a global species. 
Carcupino, M., Baldacci, A., Mazzini, M. \& Franzoi, P., 2002. Functional significance of the male brood pouch in the reproductive strategies of pipefishes and seahorses: a morphological and ultrastructural comparative study on three anatomically different pouches. Fournal of Fish Biology, 61, 1465-1480.

Cowen, R.K., Lwiza, K.M., Sponaugle, S., Paris, C.B. \& Olson, D.B., 2000. Connectivity of marine populations: open or closed? Science, New York, 287, 857-859.

Dawson, C.E., 1986. Syngnathidae. In Fishes of the North-eastern Atlantic and the Mediterranean (ed. P.J.P. Whitehead et al.), pp. 628-639. Paris: Unesco.

Froese, R. \& Pauly, D., 2004. FishBase. World Wide Web electronic publication.

Herald, E.S., 1959. From pipefish to seahorse - a study of phylogenetic relationships. Proceedings of the Californian Academy of Sciences, 29, 465-473.

Lourie, S.A., Green, D.M. \& Vincent, A.C.J., 2005. Dispersal, habitat differences, and comparative phylogeography of Southeast Asian seahorses (Syngnathidae: Hippocampus). Molecular Ecology, 14, 1073-1094.

Monteiro, N.M., Almada, V.G. \& Vieira, M.N., 2003. Early life history of the pipefish Nerophis lumbriciformis (Pisces: Syngnathidae). Fournal of the Marine Biological Association of the United Kingdom, 83, 1179-1182.
Monteiro, N.M., Almada, V.C. \& Vieira, M.N., 2005 Implications of different brood pouch structures in syngnathid reproduction. Fournal of the Marine Biological Association of the United Kingdom, 85, 1235-1241.

Rè, P., 1999. Ictioplâncton estuarino da Península Ibérica (Guia de identificação dos ovos e estados larvares planctónicos), 163 pp, 51. Câmara Municipal de Cascais.

Russell, F.S., 1976. The eggs and planktonic stages of British marine fishes. London: Academic Press.

Silva, K., Monteiro, N.M., Almada, V.G. \& Vieira, M.N., 2006. Early life history of Syngnathus abaster (Pisces: Syngnathidae). Journal of Fish Biology, 68, 80-86.

Teixeira, R.L. \& Musick, J.A., 1995. Trophic ecology of two congeneric pipefishes (Syngnathidae) of the lower York River, Virgínia. Environmental Biology of Fishes, 43, 295-309.

Vincent, A., Ahnesjo, I., Berglund, A. \& Roseqvist, G., 1992. Pipefishes and seahorses: are they all sex role reversed? Trends in Ecology and Evolution, 7, 237-241.

Wilson, A.B., Ahnesjo, I., Vincent, A.C.J. \& Meyer, A., 2003. The dynamics of male brooding, mating patterns, and sex roles in pipefishes and seahorses (Family Syngnathidae). Evolution, 57, 1374-1386.

Submitted 23 February 2006. Accepted 9 October 2006. 